\title{
Analysis of thermal properties, water vapor resistance and radiant heat transmission through different combinations of firefighter protective clothing
}

Analiza proprietăților termice, rezistența la vapori de apă și transmisia căldurii radiante prin diferite combinații de îmbrăcăminte de protecție pentru pompieri

Această lucrare experimentală este un efort de a identifica posibilitatea îmbunătățirii performanței de protecție termică a îmbrăcămintei de protecție pentru pompieri la diferite niveluri de densitate a fluxului de căldură. Îmbunătătirea performanțelor de protecție termică înseamnă îmbunătătirea timpului de expunere la fluxul de căldură, ceea ce va oferi un timp suplimentar pompierilor pentru a-și îndeplini sarcinile, fără să sufere leziuni grave. Au fost investigate patru combinații multistrat diferite de îmbrăcăminte de protecție pentru pompieri. Fiecare combinație constă dintr-o carcasă exterioară, barieră împotriva umidității și căptușeală termică. De asemenea, a fost utilizată foaie de aerogel ca înlocuitor al barierei termice. Inițial, s-au investigat proprietăți cum ar fi rezistența termică, conductivitatea termică și rezistența la vapori de apă ale ansamblurilor de țesături multistrat. Ulterior, aceste combinații au fost expuse unor niveluri diferite de densitate a fluxului de căldură radiantă, de exemplu la 10, 20 și $30 \mathrm{~kW} / \mathrm{m}^{2}$ conform standardului ISO 6942 . S-a observat că acele combinații în care pătura de aerogel a fost utilizată ca barieră termică dobândesc o rezistență termică mai mare, rezistență la vapori de apă și valori mai reduse ale densității fluxului de căldură transmisă.

Cuvinte-cheie: îmbrăcăminte de protecție pentru pompieri, rezistență termică, performanța de protecție termică, densitatea fluxului de căldură

\section{Analysis of thermal properties, water vapor resistance and radiant heat transmission through different} combinations of firefighter protective clothing

This experimental work is an effort to seek the possibility of improvement in thermal protective performance of firefighter protective clothing at different levels of heat flux density. Improvement in thermal protective performance means enhancement in the time of exposure against the heat flux, which will provide extra time to firefighters to perform their duties without suffering from severe injuries. Four different multilayer combinations of firefighter protective clothing were investigated. Each combination consists of outer shell, moisture barrier and thermal liner. Aerogel sheet was also employed as a substitute to thermal barrier. Initially, properties like thermal resistance, thermal conductivity, and water vapor resistance of multilayer fabric assemblies were investigated. Later on these combinations were exposed to different levels of radiant heat flux density i.e. at 10, 20 and $30 \mathrm{~kW} / \mathrm{m}^{2}$ as per ISO 6942 standard. It was noted that those combinations in which aerogel blanket was used as thermal barrier acquire greater thermal resistance, water vapor resistance and have less transmitted heat flux density values.

Keywords: firefighter protective clothing, thermal resistance, thermal protective performance, heat flux density

\section{INTRODUCTION}

Firefighter protective clothing is multi-layer garment which secures the firefighter from threats like external radiant heat flux, chemical spillage, flame and delivers thermal equilibrium to human body [1]. Firefighter protective clothing comprises of exterior shell, moisture barrier and thermal barrier [1-3]. The exterior shell comprises of those substrates which are developed to have contact with flame and heat without degenerating or burning i.e. they prevent ignition when have direct contact with flame and must have property of water repellence and good thermal insulation. Mostly fibers like meta-aramids (Nomex), combination of meta-aramid and paramid (Nomex III A), polybenzimidazole (PBI), Zylon and some fibers with flame resistant finishes like Proban and Pyrovatex are utilized in outer layers. The moisture barrier is located between exterior layer and thermal barrier.
This layer is impermeable to water but permeable to water vapors. Its primary objective is to shield the body of firefighters from blood pathogens and liquefied chemicals. Moisture barrier is micrporous membrane available in the market as Goretex, Proline, Cross tech, Action, Neo Guard. The thermal barrier protects human body by blocking the environmental heat and utilizes flame retardant fibers and their blends. It can be nonwoven, quilted batting, laminated woven, lining fabric and knitted fabric and spun laced [3-6]. In terms of protective performance of firefighters, time is the main factor. Enhancement in thermal protection increases the time period for firefighter to carry out their activities without any significant injuries. As a result, firefighters can spend more time in hazardous environment saving precious lives and damages caused by fire without injuring themselves [7-9]. Thermal protective performance is 
influenced by several factors like thermal conductivity, water vapor resistance and impact of air gaps [7]. Thermal protective performance is evaluated by several tests like bench scale test (Heat guard plate, TPP tester) [10-14] or full scale test methodology like thermal manikin [15-16]. Several scientific investigations inculcating numerical models and experimental studies were performed under different levels of radiant heat exposure to study thermal protective performance of firefighter protective clothing. These studies employ test methodologies from bench scale testing to full scale manikin to evaluate the thermal protective behavior of clothing under various levels of radiant heat exposure [17].

For enhancing the thermal protection of firefighters, the utility of silica based aerogel or aerogel blankets in firefighter protective clothing is the focus of attraction for many researchers. It is a light weight porous substrate synthesized from gel by substituting liquid phase with gaseous phase [18-19]. There are several different types of aerogels. Among all of them, silica based aerogels have very interesting properties because of their inflammable nature and lower thermal conductivity than air in same conditions [20]. Silica based aerogel is hydrophobic substrate having porosity greater than $90 \%$ and specific surface area of nearly $1000 \mathrm{~m}^{2} / \mathrm{g}$. The thermal conductivity of silica based aerogel is approximately $0.015 \mathrm{~W} / \mathrm{mK}$ [21-22]. All of these characteristics make silica based aerogels a favorable candidate for utility in firefighter protective clothing as thermal barrier. Silica based aerogels are available on commercial basis as Nanongel particles by Cabot corporation and as pyrogel blankets by Aspen aerogel [23]. Pyrogel 2250 is flexible blanket consisting of trimethylsilylated silica gel and oxidized polyacrylonitrile fiber (OPAN) [24].
Oxidized polyacrylonitrile fiber has outstanding insulation properties and very high Limiting Oxygen Index (LOI) [25].

The main aim of this research is to enhance thermal protective performance of firefighter protective clothing. For this purpose four combinations of high performance fabrics were made. Each corresponding combinations were characterized by Alambeta and Permetest. Afterwards, these combinations were evaluated by X637 B machine (ISO 6942 standard) for determining transmission of heat through multilayer protective clothing assemblies at $10 \mathrm{~kW} / \mathrm{m}^{2}$, $20 \mathrm{~kW} / \mathrm{m}^{2}$ and $30 \mathrm{~kW} / \mathrm{m}^{2}$ to evaluate the thermal protective performance in terms of transmitted flux density $Q_{C}$ and \% age transmission factor.

\section{EXPERIMENTATION}

\section{Materials and methodology}

All fabric layers utilized in firefighter protective clothing for this experimentation were supplied by Kivanc group Turkey and Vochoc Company Czech republic. Aerogel blanket (Pyrogel 2250) was supplied by Ayvaz Yalitim Company from Turkey. This layer was used as substitute layer to thermal barrier. Two different outer shells, one moisture barrier and one thermal liner were employed. Four different combinations of clothing assemblies were prepared (table 1 and table 2).

\section{Thermal conductivity and thermal resistance}

Evaluation of thermal resistance, thermal conductivity and thickness of monolayer and multilayer protective clothing arrangement was done with the help of Alambeta (non-destructive method), a patent of Prof. Lubos Hes [27] manufactured by Sensora company is a computer controlled device measuring thermal

\begin{tabular}{|c|c|c|c|c|c|}
\hline \multicolumn{7}{|c|}{ Layer } & $\begin{array}{c}\text { Fabric } \\
\text { code }\end{array}$ & Component & Weave type & $\begin{array}{c}\text { Fabric weight } \\
\left(\mathbf{g} / \mathbf{m}^{2}\right)\end{array}$ & $\begin{array}{c}\text { Thickness } \\
(\mathbf{m m})\end{array}$ \\
\hline Outer layer 1 & $\mathrm{O}(1)$ & $\begin{array}{c}\% 75 \text { Metaaramid-23\% } \\
\text { Paraaramid-\%2 Antistatic }\end{array}$ & Twill & 202 & 0.488 \\
\hline Outer layer 2 & $\mathrm{O}(2)$ & Proban (100\% cotton) & Twill & 300 & 0.864 \\
\hline Moisture barrier & $\mathrm{M}$ & $\begin{array}{c}\text { PU membrane laminated } \\
\text { to nonwoven }\end{array}$ & Nonwoven & 128 & 0.94 \\
\hline Thermal liner & $\mathrm{T}$ & $\begin{array}{c}50 / 25 / 25 \text { Aramid/Viscose/FR } \\
\text { icastar }\end{array}$ & $\begin{array}{c}\text { Needlepunching } \\
\text { nonwoven }\end{array}$ & 400 & 3.424 \\
\hline $\begin{array}{c}\text { Aerogel blanket } \\
\text { (Pyrogel 2250) }\end{array}$ & $\mathrm{P}$ & $\begin{array}{c}\text { Silica aerogel with reinforced } \\
\text { polymers }\end{array}$ & Nonwoven & 400 & 2.78 \\
\hline
\end{tabular}

\begin{tabular}{|c|c|c|c|c|}
\hline Sr \# & $\begin{array}{c}\text { Fabric arrangement in multilayer } \\
\text { clothing assembly }\end{array}$ & $\begin{array}{c}\text { Fabric } \\
\text { code }\end{array}$ & $\begin{array}{c}\text { Thickness } \\
(\mathbf{m m})\end{array}$ & $\begin{array}{c}\text { GSM } \\
\left(\mathbf{g} / \mathbf{m}^{2}\right)\end{array}$ \\
\hline 1 & Outer shell (1) + Moisture barrier + Thermal liner & $\mathrm{A}$ & 5.202 & 730 \\
\hline 2 & Outer shell (2) + Moisture barrier + Thermal liner & B & 5.362 & 828 \\
\hline 3 & Outer shell (1) + Moisture Barrier + Aerogel sheet & C & 4.638 & 730 \\
\hline 4 & Outer shell (2) + Moisture Barrier + Aerogel sheet & D & 4.776 & 828 \\
\hline
\end{tabular}


characteristics of monolayer and multilayer protective layers as per EN 31092 standard [26-27]. Five measurements were taken for each sample.

Relative water vapor permeability (RWVP \%age) and water vapor resistance $\left(R_{\text {et }}\right)$

Water vapor resistance $R_{\text {et }}\left(\mathrm{m}^{2} \mathrm{~Pa} / \mathrm{W}\right)$ and relative water vapor permeability (RWVP\% age) under steady state conditions was evaluated by PERMETEST (non-destructive method) which is also patent of Prof. Lubos Hes and was developed by Sensora company as per ISO 11092 standard [28]. The higher the value of relative water vapor permeability, the lesser will be the water vapor resistance and there will be better thermal comfort [29]. Five measurements were taken for each specimen.

The radiant heat testing equipment

The radiant heat testing equipment X637 B Protective clothing was used to measure radiant heat transmission through material or material assembly according to ISO 6942 standard. This equipment consists of small curved copper plate calorimeter with area of $(50 \mathrm{~mm} \times 50.3 \mathrm{~mm})$ with mass of 35.9 to 36 grams. A radiation heat source consisting of six carbide heating rods along with moveable test frame having cooling device and specimen holders is shown in figure 1 . The size of the sample was 230 $\mathrm{mm} \times 80 \mathrm{~mm}$ which is placed on the face side of calorimeter and subjected to a specific level of radiant heat and time for temperature escalation of $12^{\circ} \mathrm{C}$ and $24^{\circ} \mathrm{C}$ (RHTI12 and $\mathrm{RHTI} 24$ ) in the calorimeter was noted and outcomes are articulated as radiant heat transmission index and the \% age heat transmission factor [30]. Five specimens are required for testing at each level of heat flux density.

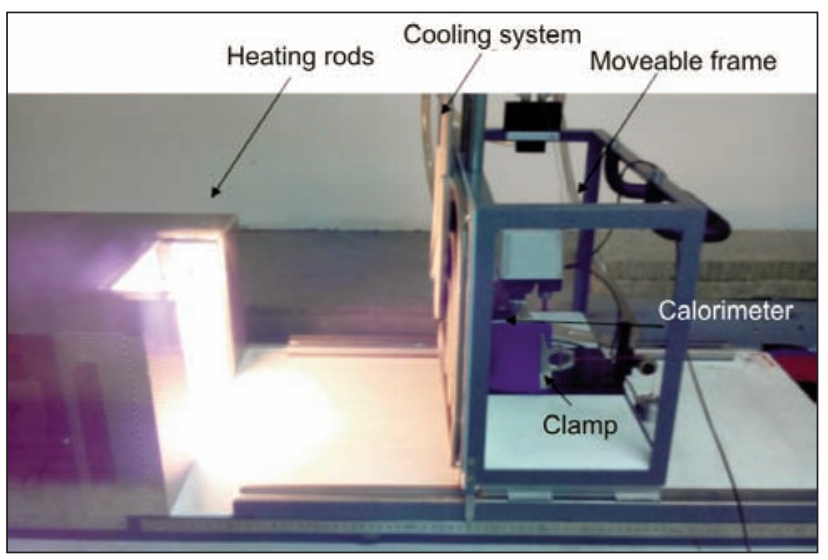

Fig. 1. Radiation heat testing equipment

\section{RESULTS AND DISCUSSION}

\section{Evaluation of thermal conductivity and thermal resistance}

Thermal conductivity, thermal resistance and thickness were evaluated by Alambeta for monolayer and multilayer protective fabric assemblies and their corresponding values were mentioned in figure 2 respectively. Thermal resistance, $R_{t h}$, of textile substrate is a function of the actual thickness of the textile fabric and its thermal conductivity. This relationship is given by following equation:

$$
R_{t h}=\frac{h}{\lambda}
$$

$R_{t h}$ is thermal resistance $\left(\mathrm{m}^{2} \mathrm{~K} / \mathrm{W}\right), h$ - thickness of textile substrate. This thermal resistance is inversely proportional to thermal conductivity. Thermal conductivity and thermal resistance are not only contingent on thickness of the fabric assemblies and but also on physical and chemical properties of textile substrate. Greater the thickness, greater will be the thermal resistance of the material. However, this is not only the whole scenario, the porosity and density of the textile substrate also plays a vital role in thermal behavior of the medium. Textile substrate with closed and small pores is able to trap air inside the substrate. The illustration of this phenomenon is the due to fact that air has a lower thermal conductivity than materials constituting the sample [31]. On the other hand, thermal conductivity enhances with the relative humidity absorbed by the material [32]. Consequently, the thermal conductivity of highly hygroscopic material is more as compared to less hygroscopic substrate. From figure 2, it can be noted that a high value of thermal resistance was witnessed in arrangement of multilayer protective clothing having aerogel layer as an alternate to thermal liner (sample $C$ and D). There might be several reasons. One reason might be that this substitute layer encloses silica based aerogel which has very less thermal conductivity even lower than still air. Because of porosity and nanometer pore size, silica based aerogels are highly insulating materials [30].

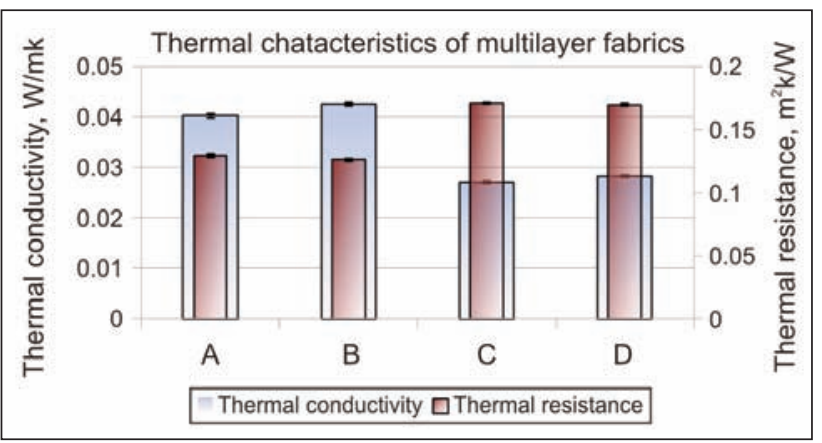

Fig. 2. Thermal conductivity and thermal resistance values of multilayer protective clothing

By means of mass, Aerogel is $96 \%$ of air making it least dense man-made substrate [30]. Because of gaseous structure of aerogel and low thermal conductivity of gas, there might be blockage of conductive heat transfer [34]. The porous architecture of aerogel is responsible for gaseous structure of aerogel [35-36]. In addition to that, convective heat transfer is deterred because construction of aerogel does not allow circulation of air [34]. The other reason is that this aerogel blanket also contains oxidized polyacrylonitrile (OPAN) fiber which has very low thermal conductivity $(0.030 \mathrm{~W} / \mathrm{mK})$ and very high limiting 
oxygen Index (LOI) i.e. almost $45 \%$ which is greater than LOI of meta aramid, para aramids and PBI. Moreover it has outstanding flame resistant properties as compared to the high performance fibers [24] which ultimately results in high thermal resistance in monolayer and multilayer fabric assemblies. Consequently, specimen C and D which employ aerogel layer as an alternate to thermal barrier offers more thermal resistance as compared to specimen $A$ and $B$. On the other hand, thermal resistance of specimen $A$ was slightly greater than specimen $B$. This might be due to the fact that specimen $A$ has outer shell $\mathrm{O}(1)$ containing $75 \%$ and $23 \%$ of meta aramid and para aramid fibers respectively which have inherent flame retardant and better insulation characteristics as compared to specimen B in which the main ingredient of outer layer is cellulosic material (cotton) which offers more thermal conductivity and less thermal resistance as compared to outer layer of specimen A [36].

\section{Evaluation of water vapor resistance}

Water vapor resistance was determined by PERMETEST apparatus which gives two values i.e. relative water vapor permeability (RWVP\%) and water vapor resistance $\left(R_{e t}\right)$. Barker et al mentioned that the influence of moisture on thermal protective performance is a function of exposure conditions, amount of moisture in the turnout system and its permeability and insulation properties [37]. A careful analysis of figure 3 revealed that more water vapor resistance was witnessed in specimen $C$ and $D$ utilizing aerogel blanket. This might be due to hydrophobic nature of aerogel and presence of closed pores inside the structure of aerogel blanket. However, still there was some water vapor permeability in specimen $C$ and $D$ which might be due to the high absorbing capabilities of aerogel, enabling the aerogel blanket (pyrogel 2250 sheet) to absorb moisture due to wetting and transport it to environment, especially when it was placed next to skin despite of the fact that aerogel has very low air permeability [38-43]. It was also witnessed by Xiamong et al. that there was no significant relationship between air permeability and water vapor permeability in case of multilayer assemblies having aerogel particles sprayed between the layers [43]. As the percentage of aerogel increases more amount of water vapor permeability was witnessed and less permeability of air was observed.

It might be noticed that low water vapor resistance can sometimes create problem if exterior pressure is high as compared to interior pressure inside clothing allowing the moisture to breach inside the garments instead of evacuating it out of the garment.

The type of fibers plays a key role in moisture vapor permeability. An examination of figure 3 reveals that specimen having meta-aramid as outer shell offer slightly more water vapor resistance $R_{\text {et }}$ as compared to combinations having probanas outer shells. This might be due to fact that Meta aramid has less moisture regain but greater wicking ability as compared to proban which have cellulosic content. Consequently,

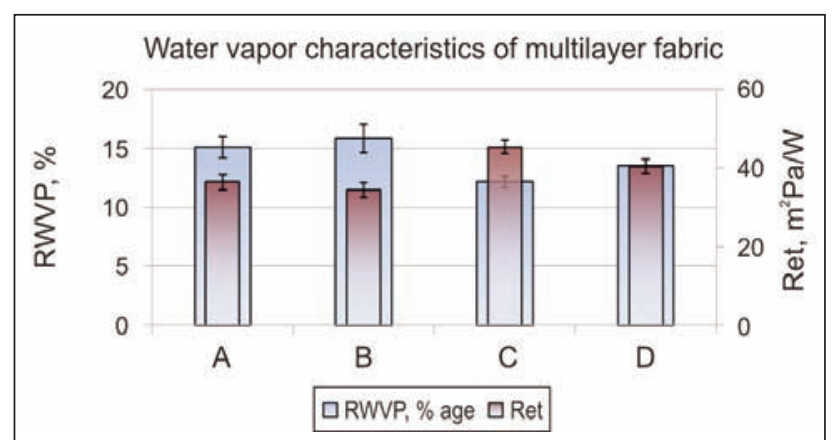

Fig. 3. Water vapor resistance and relative water vapor permeability \%age of multilayer protective clothing

specimen having meta-aramid as outer shell has higher $R_{\text {et }}$ values [38].

\section{Transmission of radiant heat flux through multilayer protective clothing}

This apparatus comprises of a radiation heat source which can generate heat flux density up to $80 \mathrm{~kW} / \mathrm{m}^{2}$ along with calorimeter which evaluates heat flux. The outcomes of this test are the two threshold times i.e. Radiant heat transfer index (RHTI 24 and RHTI 12) respectively, incident heat flux density $\left(Q_{0}\right)$ and transmitted heat flux density $\left(Q_{C}\right)$ and percentage heat transmission factor (\%age $T F$ ) (table 3 ).

RHTI $12=$ Threshold time in (sec) when temperature of calorimeter increase in $12^{\circ} \mathrm{C}$.

RHTI $24=$ Threshold time in (sec) when temperature of calorimeter increase in $24^{\circ} \mathrm{C}$

$$
Q_{0}=\frac{C_{p} R M}{a \cdot A}
$$

$R$ is rate of rise of the calorimeter temperature in the linear region in ${ }^{\circ} \mathrm{C} / \mathrm{s} ; M$ - mass of copper plate in $\mathrm{kg}$; $C_{p}$ - specific heat of copper $0.385\left(\mathrm{~kJ} / \mathrm{Kg}^{\circ} \mathrm{C}\right) ; a-$ the absorption coefficient of the painted surface of calorimeter; $A$ - area of the copper plate in $\mathrm{m}^{2}$.

The transmitted flux density, $Q_{C}$ in $\mathrm{kW} / \mathrm{m}^{2}$, is evaluated by the following equation:

$$
Q_{c}=\frac{M C_{p} 12}{A .(R H T I 24-R H T I 12)}
$$

$\frac{12}{R H T I 24-R H T I 12}$ is mean rate of rise of the calorimeter temperature in ${ }^{\circ} \mathrm{C} / \mathrm{s}$ in the region between a $12^{\circ} \mathrm{C}$ and $24^{\circ} \mathrm{C}$ rise where $\mathrm{RHTI} 12$ indicates time to acquire increase of $(12 \pm 0.1)^{\circ} \mathrm{C}$ rise in temperature. RHTI 24 means time to attain increment of $(24 \pm$ $0.2)^{\circ} \mathrm{C}$.

Equation 4 delivers the percentage heat transmission factor, $\%$ age $\operatorname{TF}\left(Q_{0}\right)$ for incident heat flux density level.

$$
\% \text { age } T F=100 \cdot \frac{Q_{C}}{Q_{O}}
$$

A perusal of table 3 reveals that values of transmitted heat flux density $Q_{c}$ and percentage Transmission factor (\%age TF) increases sequentially with increase in level of incident heat flux density. It was also noted 


\begin{tabular}{|c|c|c|c|c|c|c|c|}
\hline $\mathrm{Sr} \#$ & $\begin{array}{l}\text { Name of } \\
\text { material }\end{array}$ & $\begin{array}{c}{ }^{*} Q_{0} \\
\left(\mathrm{~kW} / \mathrm{m}^{2}\right)\end{array}$ & RHTI12 & RHTI24 & RHTI24-RHTI12 & $Q_{c}\left(k W / m^{2}\right)$ & \%age TF \\
\hline 1 & $P$ & 10 & $54.55 \pm 2.828$ & $102.6 \pm 2.969$ & 48.05 & $1.36 \pm 0.006$ & 0.136 \\
\hline 2 & A & 10 & $58.2 \pm 0.424$ & $101.0 \pm, 0.015$ & 42.8 & $1.55 \pm 0.014$ & 0.155 \\
\hline 3 & B & 10 & $74.1 \pm .707$ & $128.65 \pm 2.757$ & 54.55 & $1.212 \pm 0.045$ & 0.121 \\
\hline 4 & C & 10 & $84.55 \pm 0.777$ & $163.35 \pm 3.181$ & 78.8 & $0.839 \pm 0.026$ & 0.083 \\
\hline 5 & D & 10 & $97.4 \pm 6.929$ & $195 \pm 2.5738$ & 97.6 & $0.677 \pm 0.132$ & 0.067 \\
\hline 1 & $P$ & 20 & $33.25 \pm 5.727$ & $54.15 \pm 8.273$ & 20.9 & $3.164 \pm 0.390$ & 0.158 \\
\hline 2 & A & 20 & $36.7 \pm 0.989$ & $57.05 \pm 1.343$ & 20.35 & $3.249 \pm 0.056$ & 0.162 \\
\hline 3 & B & 20 & $46.7 \pm 6.081$ & $58.55 \pm 6.293$ & 11.85 & $5.580 \pm 0.100$ & 0.279 \\
\hline 4 & C & 20 & $44.6 \pm 0.457$ & $70.8 \pm 2.596$ & 26.2 & $2.524 \pm 0.050$ & 0.126 \\
\hline 5 & D & 20 & $58.15 \pm 0.919$ & $79.956 \pm 1.484$ & 21.806 & $3.033 \pm 0.079$ & 0.151 \\
\hline 1 & $P$ & 30 & $33.3 \pm 0.141$ & $48.75 \pm 0.353$ & 15.45 & $4.280 \pm 0.058$ & 0.142 \\
\hline 2 & $A$ & 30 & $27.85 \pm 0.070$ & $40.35 \pm 0.494$ & 12.5 & $5.290 \pm 0.181$ & 0.176 \\
\hline 3 & $B$ & 30 & $31.4 \pm 2.121$ & $38.15 \pm 2.474$ & 6.75 & $9.79 \pm 0.516$ & 0.326 \\
\hline 4 & C & 30 & $41.5 \pm 1.272$ & $61 \pm 2.969$ & 19.5 & $3.391 \pm 0.297$ & 0.113 \\
\hline 5 & $D$ & 30 & $44.15 \pm 1.626$ & $59.8 \pm 1.272$ & 15.65 & $4.225 \pm 0.096$ & 0.140 \\
\hline
\end{tabular}

* $\mathrm{RHTI}=$ Radiant heat transfer index.

that minimum values of transmitted flux density $Q_{c}$ $\left(\mathrm{kW} / \mathrm{m}^{2}\right)$ were observed for the samples having aerogel blanket as thermal liner. A similar pattern was also noted in \%age TF values for the specimen having aerogel sheet [41]. This might be due to fact that silica based aerogel blanket contains almost $96 \%$ of air and air is a good insulator blocking the amount of heat passed through the specimen. Moreover, these aerogel samples consist of oxidized polyacrylonitrile polymer which have very good thermal stability and can withstand higher amount of heat flux and has very high limiting oxygen index (LOI) of almost $45 \%$ [40]. The lower the value of transmitted heat flux density, the lesser will be amount of heat passed through fabric assemblies towards calorimeter allowing more time to firefighter to perform their duties before acquiring burn injuries. Table 3 also depicts that greater difference between RHTI 24 and $R H T I$ 12, lesser will be the value of transmitted flux density $Q_{c}\left(\mathrm{~kW} / \mathrm{m}^{2}\right)$ and \%age $T F$ respectively, which indicates that specimen can withstand respected heat flux for longer time period allowing firefighters to perform their duties for longer duration before getting burn injuries. At $10 \mathrm{~kW} / \mathrm{m}^{2}$, the lowest values of $Q_{C}$ and \%age $T F$ were witnessed for specimen $C, D$. These values were higher for specimen $A$ and $B$ having no aerogel blanket. It was also noted that there was minor difference in the values of $Q_{C}$ and \%age $T F$ values for aerogel sheet, sample $A$ and specimen $B$ respectively. At $20 \mathrm{~kW} / \mathrm{m}^{2}$, the situation was slightly different i.e. the $Q_{c}$ and \%age $T F$ values of specimen $B$ is significantly higher than rest of the samples and negligible difference for the values of $Q_{c}$ and \%age TF was witnessed for

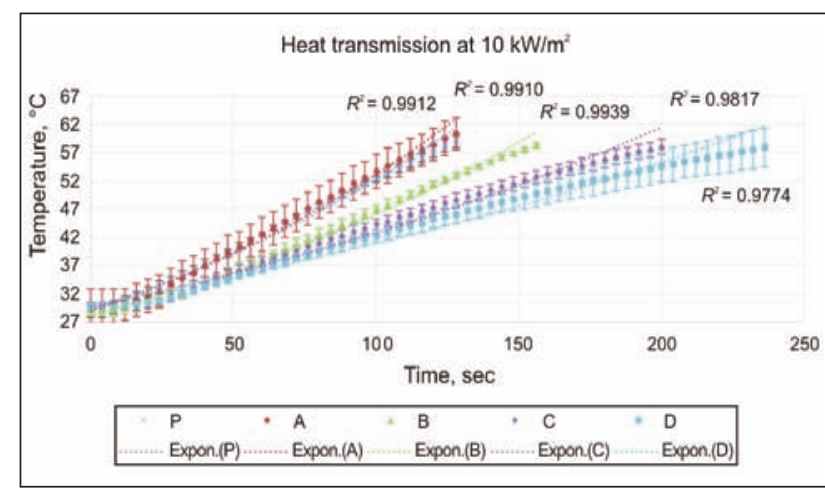

Fig. 4. Heat transmission at $10 \mathrm{~kW} / \mathrm{m}^{2}$

aerogel sheet, specimen $A$ and specimen $D$. The lowest value of \%age TF and $Q_{c}$ for $20 \mathrm{~kW} / \mathrm{m}^{2}$ was observed for specimen C. At $30 \mathrm{~kW} / \mathrm{m}^{2}$, a trend similar to that of $20 \mathrm{~kW} / \mathrm{m}^{2}$ was noted i.e. the least value of $Q_{C}$ and \%age $T F$ was observed for sample $C$ and highest value was observed sample $B$. However, this time there was significant difference in values $Q_{c}$ and $\%$ age $T F$ for specimen $A$ and aerogel sheet.

A glance at figure 4 reveals that at $10 \mathrm{~kW} / \mathrm{m}^{2}$ the curve of specimen $D$ and specimen $C$ are much flatter as compared to the curves of specimen B, specimen $A$ and aerogel layer $(P)$ respectively. The flatter the curve, the slower will be rate of increase in temperature, which will give more time of exposure to specimen when subjected to radiant heat flux. The flatter curve also indicates less damage to the corresponding fabric layers of the specimen. However, there were no gaps in the curves of aerogel blanket and specimen A, which have very close values of $Q_{C}$ 


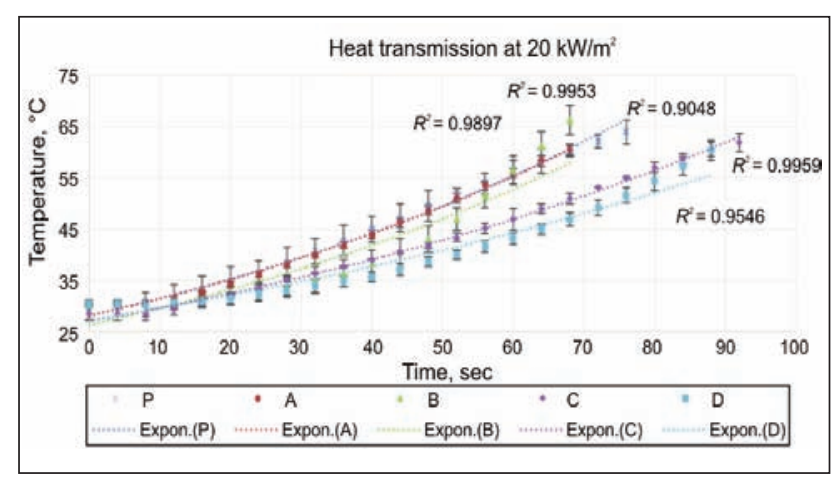

Fig. 5. Heat transmission at $20 \mathrm{~kW} / \mathrm{m}^{2}$

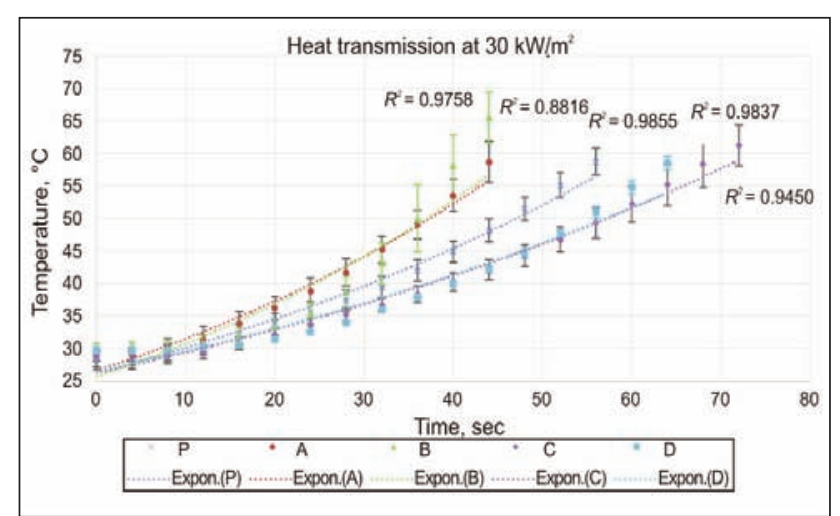

Fig. 6. Heat transmission at $30 \mathrm{~kW} / \mathrm{m}^{2}$ and TF. Figure 4 also depicts clear gap between curves of specimen $B$ and curves of specimen $A$ and aerogel blanket $(P)$, which is also highlighted from the values of $Q_{C}$ and \% age TF from table 3 .

From figure 5 , it can be seen that at $20 \mathrm{~kW} / \mathrm{m}^{2}$, there was quite similarity between the curves of specimen $A$ and aerogel sheet $(P)$. The pattern of the curve $B$ at $20 \mathrm{~kW} / \mathrm{m}^{2}$ was different than that of the curve of specimen $B$ at $10 \mathrm{~kW} / \mathrm{m}^{2}$. The rate of increase of temperature was smooth till $50 \mathrm{sec}$ for specimen B but after wards there was sharp increment in the rate of increase of temperature which indicates sudden damage to the corresponding layers of specimen $B$ as the time of exposure increases. The curve of specimen $C$ was much flat and there was no unusual variation. However, in case of specimen $D$, the pattern of the curve was flat till $70 \mathrm{sec}$ but later on it becomes very steep indicating certain damage to layers of specimen especially the outer layer. This is also evident from values of $Q_{C}$ and \%age $T F$ which are more than that of specimen $\mathrm{C}$.

In case of $30 \mathrm{~kW} / \mathrm{m}^{2}$ from figure 6 , there was dissimilarity in the pattern of the curves for aerogel blanket and specimen A showing that there was more damage of fibers at higher flux density as compared to aerogel blanket. But the curve of specimen $B$ shows irregularity after $30 \mathrm{sec}$ showing sudden sharp increment in the temperature, which is clear indication of decrease in thermal protective behavior of specimen due to damage of fiber which allows swift passage of heat after $30 \mathrm{sec}$ causing increase in values of $Q_{C}$ and \%age TF. The curve of specimen D was short as compared to curve of specimen C. However, after $70 \mathrm{sec}$, there was irregular increase in temperature for specimen $D$ due to which greater values of $Q_{C}$ and \%age TF are witnessed in table 3 for specimen $D$.

The curve of specimen $\mathrm{C}$ was regular, flat and long showing better thermal protective behavior of specimen $\mathrm{C}$ at $30 \mathrm{~kW} / \mathrm{m}^{2}$. Thus the fabric assembly having aerogel has better thermal protective behavior as compared to other samples. This might be due to fact that Infrared radiation that plays a significant role in transference of heat can also be absorbed by aerogel [40-42] due to which aerogel blanket offers better thermal stability and insulation as compared to other specimen.

\section{CONCLUSION}

It can be inferred that safety of firefighters is dependent on the protective performance of firefighter protective clothing. If this protective performance can increase time of exposure of firefighters against heat flux, it may result in saving precious lives and useful stuff. It was also witnessed that there was significant increase in thermal resistance and water vapor resistance when aerogel blanket was utilized as alternative layer to thermal barrier and when meta-aramid layer was utilized as outer shell. When the samples were exposed to various levels of heat flux density, it was noticed that those combinations in which metaaramid and aerogel substrate was utilized deliver better thermal stability especially when subjected to high heat flux densities. This might be due to the nature of fibers involved in these substrates which offers better thermal stability against higher level of heat flux. However, it was also witnessed that there was overall trend of increase in transmitted heat flux density with increase of incident heat flux density. This might be due to damage incur to fibers in different layers as a result of which thermal stability is decreased at higher heat flux densities. The use of aerogel shows significant improvement for thermal protection of firefighter clothing and can be used when high range protection is required from heat.

\section{ACKNOWLEDGMENT}

This study is supported under student grant scheme of SGS-21246 from Technical University of Liberec Czech Republic. We would also especially like to thank Ayvaz Yalitim Company from Turkey for providing us samples of aerogel sheet. 
[1] Lawson, J.R. Fire fighters protective clothing and thermal environments of structural fire-fighting. In: ASTM Spec Tech Publ, 1997, vol. 1273, pp. 334-335.

[2] Rajkishore, N., Shadi, H., Padhye, P. Recent trends and future scope in protection and comfort of fire-fighter's personal protective clothing. In: Fire Science Reviews, 2014, vol. 3, p. 4

[3] Lu, J., Kyounga, H., Keejong, Y., Effect of aerogel on thermal protective performance of firefighter clothing. In: Journal of Fiber Bioengineering and Informatics, 2013, vol. 6, pp. 315-324.

[4] Song, G., Paskaluk, S., Sati, R. Thermal protective performance of protective clothingused for low radiant heat protection. In: Text Res J, 2011, vol. 81, pp. 311-323.

[5] Kinen, H.M. Firefighter's protective clothing. In: Scott R.A. (ed.) Textiles for protection, 2005, Woodhead Cambridge, UK, pp. 622-647.

[6] Tolera, A.N., Master thesis, Department of Textile Engineering, Istanbul Technical University, 2015.

[7] Holcombe B.V. The heat related properties of fire fighters protective clothing fabrics. In: Fire Safety Journal, 1983, vol. 6, pp. 129-141.

[8] NFPA, Protective clothing ensemble for structural fire fighting, In: National Fire Protection Association, 1997, Quincy, MA.

[9] Schacher, D.A., Drean, C.Y. Comparison between thermal insulation and thermal properties of classical and microfibres polyester fabrics. In: International Journal of Clothing Science and Technology, 2000, vol. 12(2), pp. 84-95.

[10] Salmon, D. Thermal conductivity of insulations using guarded hot plates, including recent developments and sources of reference materials. In: Measurement Science and Technology, 2001, vol. 12, pp. 1-89.

[11] Huang, J.H. Thermal parameters for assessing thermal properties of clothing. In: Journal of Thermal Biology, 2006, vol. 31, pp. 461-466.

[12] ISO 11092, Textiles - Physiological Effects - Measurement of Thermal and Water Vapour Resistance Under Steady-State Conditions (Sweating Guarded Hotplate Test). In: International Organization for Standardization, 1993, Geneva.

[13] ASTM 1868, Standard Test Method for Thermal and Evaporative Resistance of Clothing Materials Using a Sweating Hot Plate. In: American Society for Testing and Materials, 2005, West Conshohocken, PA.

[14] Chen, Y.S., Fan, J.T., Zhang, W. Clothing thermal insulation during sweating. In: Textile Research Journal, 2003, vol. 73, pp. 152-157.

[15] Celcar, D., Meinander, H., Jelka, G. Heat and moisture transmission properties of clothing systems evaluated by using a sweating thermal manikin under different environmental conditions. In: International Journal of Clothing Science and Technology, 2008, vol. 20, pp. 240-252.

[16] Lee, J., Ko, E., Lee, H., Kim, J., Choi, J. Validation of clothing insulation estimated by global and serial methods. In: International Journal of Clothing Science and Technology, 2011, vol. 23, pp. 184-198.

[17] ISO 6942, Protective clothing - Protection against heat and fire - evaluation of materials and material assemblies when exposed to a source of radiant heat, 2002.

[18] Thapliyaland, P.C., Singh, K. Aerogels as promising thermal insulating materials: An overview. In: Journal of Material, 2014, vol. 10, pp. 1-10.

[19] Pierre, A.C. and Rigacci, A. $\mathrm{SiO}_{2}$ Aerogels, In: Aegerter M.A., Leventis N., Koebel M.M. (eds) Aerogels handbook. New York: Springer, 2011, pp. 21-45.

[20] Bheekhun, N., Abu Talib, A.R., Hassan, M.R. Aerogels in aerospace: An overview. In: Ad MaterSciEng, 2013 , vol. 2013, pp. 1-18.

[21] Mulder, C., Lierop, J.V. Preparation, densification and characterization of autoclavedried $\mathrm{SiO}_{2}$ gels, In: Fircke J. (ed.) Aerogels, 1986, New York: Springer, pp. 68-75.

[22] Pierre, A.C., Pajonk, G.M. Chemistry of aerogels and their applications. In: Chem Rev, 2002, vol. 102, pp. 4243-4265.

[23] Hrubesh, L.W. Aerogel applications. In: J Non-cryst Solids, 1998, vol. 225, pp. 335-342.

[24] Aspen aerogels, Safety data sheet, pyrogel 2250, 2008.

[25] Handermann, Z., Zoltek Corporation, oxidized polyacrylonitrile fiber properties, products and applications, In: Zoltek whitepaper, 2014.

[26] Matusiak, M. Thermal Insulation Properties of Single and Multilayer. In: Textiles Fibres \& Textiles in Eastern Europe, 2006, vol. 14, pp. 98-112.

[27] Matusiak, M., Sikorski, K. Influence of structure of woven fabrics on their thermal insulation properties. In: Fibres \& Textiles in Eastern Europe, 2011, vol. 19, p. 5.

[28] Hes, L., Araujo, M. Effect of mutual bonding of textile layers on thermal insulation and thermal contact properties of fabric assemblies. In: Textile Research Journal, 1996, vol. 66, p. 245

[29] Matusiak, M., Kowalczyk, S. Thermal-insulation properties of multilayer textile packages. In: AUTEX Research Journal, 2014, vol. 14. 
[30] Bogusławska-bączek, M., Hes, L. Effective water vapour permeability of wet wool fabric and blended fabrics. In: Fibres \& Textiles in Eastern Europe, 2013, vol. 1, pp. 67-71.

[31] Oğlakcioğlu, N., Marmarali, A. Thermal comfort properties of some knitted structures. In: Fibres \& Textiles in Eastern Europe, 2007, vol. 15(5-6), pp. 64-65.

[32] Hes, L., Loghin, C. Heat, moisture and air transfer properties of selected woven fabrics in wet state. In: Journal of Fiber Bioengineering and Informatics, 2009, vol. 2(3), pp. 141-149.

[33] Venkataraman, M., Mishra, R., Kotresh, T.M., Sakoi, T., Militky, J. Effect of compressibility on heat transport phenomena in aerogel-treated nonwoven fabrics. In: The Journal of Textile Institute, 2015, vol. 107, pp. 1150-1158.

[34] Meb, G.W., Gmb, H.P. Combustion behavior Test equipment, In: Keplerstraße Berlin, 2002.

[35] XU, B. An improved method for preparing monolithic aerogels based on methyltrimethoxysilane at ambient pressure Part I: Process development and macrostructures of the aerogels. In: Microporous and Mesoporous Materials, 2012, vol. 148(1), pp. 145-151.

[36] http://www.dupont.com/products-and-services/electronic-electrical-materials/electrical-insulation/brands/nomexelectrical-insulation/articles/nomex-410.html, Assessed on: 30-07-2017

[37] Barker, R.L., Heniford, R.C. Factors affecting the thermal insulation and abrasion resistance of heat resistant hydroentangled nonwoven batting materials for use in firefighter turnout suit thermal liner systems. In: J Eng Fibers Fabr, 2011, vol. 6, pp. 1-10.

[38] Baetens, R., Jelle, B.P., Gustavsen, A. Aerogel insulation for building applications: a state-of-the-art review, In: Energy and Buildings, 2011, 43(4), pp. 761-769.

[39] Shahid, A., Furgusson, M., Wang, L. Thermophysiological comfort analysis ofaerogel nanoparticle incorporated fabric for fire fighter's protective clothing. In: Chemicals and Materials Engineering, 2014, vol. 2, p. 4.

[40] Fricke, J. The pore structure determination of Aerogels. In: Springer-Verlag 1998, vol. 4, pp. 187-195.

[41] Lee, D. Thermal characterization of carbon-opacified silica aerogels. In: Journal of Non-Crystalline Solids, 1995 , vol. 186, pp. 285-290.

[42] Fricke, J. Thermal properties of silica aerogels. In: Le Journal de Physique Colloques, 1989, vol. 50, p. 4.

[43] Xiong, X., Yang, T., Mishra, R., Militky, J. Transport properties of aerogel-based nanofibrous nonwoven fabrics. In: Fibers and Polymer, 2016, vol. 17, no. 10, pp. 1709-1714.

\section{Authors:}

\section{JAWAD NAEEM ${ }^{1}$, ADNAN MAZARI $^{1}$, ENGIN AKCAGUN ${ }^{2}$, ANTONIN HAVELKA $^{1}$, ZDENEK KUS ${ }^{1}$}

${ }^{1}$ Technical University of Liberec, Faculty of Textile Engineering, Department of Clothing,

Studentska 2, Husova, 1402/2, Liberec, Czech Republic

e-mail: jawadnaeem.qau@gmail.com, adnanmazari86@gmail.com,

antonin.havelka@tul.cz, zdenek.kus@tul.cz

${ }^{2}$ Mimar Sinan Fine Arts University, Istanbul, Turkey

e-mail: enginakcagun@gmail.com

\section{Corresponding author:}

\section{JAWAD NAEEM}

e-mail: jawadnaeem.qau@gmail.com 